\title{
Development and Measurement of 5 kN $\mu$-Forming Machine
}

\author{
Aida Mahmudaha,b, Gandjar Kiswanto ${ }^{a}$ \\ a Department of Mechanical Engineering, Engineering Faculty, Universitas Indonesia, Depok \\ Kampus Baru UI, West Java, 16424 \\ Phone: 021-7270032, Fax: 021-7270033 \\ ${ }^{b}$ Department of Manufacturing Design Engineering, Politeknik Manufaktur Bandung \\ Kanayakan-Dago, Bandung, West Java, 40135 \\ Phone: 022-2500241, Fax: 022-2502649 \\ Email: gandjar kiswanto@eng.ui.ac.id
}

\begin{abstract}
The need of micro part become increasingly popular which make increase of the need of prodution technology with high accuracy, productivity, efficiency, and reliability.Metal forming technology offers the solution to answer the challenge. High produtivity, zero material losses, good mechanical properties of product, and tight tolerance is able to achieve by micro forming technology. This thing make metal-forming fit for mass production based on near net shape technology concept it offered.Miniaturized effect phenomena which was not simple on micro-scale manufacturing process, demand high accuracy level from all aspect of micro-manufacturing process, which are material, tool, machinery and process. Therefore, characteristic of microforming machine become important in defining reliability of micro-forming system. Micro-forming machine under investigation was $5 \mathrm{kN} \mu$-Forming Machine developed in Manufacturing Laboratory, Department of Mechanical Engineering, Universitas Indonesia. Modification to the machine made changes on machine characteristic. Therefore, it need characterization of the machine by measuring its geometric measurement and linear movement. The research revealed that deviation caused by imperfection of geometry of assembled machine component shown good results. Testing of linear movement of machine in one cycle show the range of deviation was 0.024 $\mathrm{mm}$ with smallest deviation was $-0.0135 \mathrm{~mm}$ while the biggest one was $0.0105 \mathrm{~mm}$. The value of deviation was below etimated value which estimated from mathematical analisys of backlash. The results of machine linear movement also gave reccomendation of effective path of $5 \mathrm{kN} \mu$ Forming Machine, which is on path along $30 \mathrm{~mm}$ to $40 \mathrm{~mm}$, from point $A$ which had been decided before.
\end{abstract}

Keywords: $\mu$--Forming Machine; charakterisation; measurement.

\section{INTRODUCTION}

Demand on component in small or micro size, known as micro part, has been increased in line with tendency to miniaturized and integrated function of system. The need to miniaturize comes from consumer of electronic appliance who demands easy use and good integration of function. Other than this, technical applications such as medical apparatus, sensor technology and optoelectronic also trigger the increase of the need to micro part.

Generally, a component called as micro-part when it has at least two dimensions in range of submilimeter [1]. The definiton of micro-part specifically always related to type of manufacturing process to produce a part in micro dimensions. In forming process of sheet material, micro-part is a part produced by deformation process of sheet material, and has to be in total dimension under $1 \mathrm{~mm}^{3}$, an has thickness of 10 to $0.300 \mu \mathrm{m}$ [2]. 
In satisfying the need of ever increasing micro-part's demand, it require correct manufacturing process, i.e. manufacturing process which offer high accuracy, productivity, efficiency, and reliability. Metal forming technology offers solution to answer this challenge. High productivity, zero material loses, good mechanical properties of material, together with tight tolerance could be achieved by micro-forming technology. This makes metal-forming fit for mass production with near net shape technology it offered. Effect on miniaturized phenomena, which are not a simple way on micro-scale manufacturing process, demands high level of accuracy from all aspect of micromanufacturing system, i.e. material, tool, machinery, and process. Therefore, characteristic of micro-forming mahine become important to decide the reliability of microforming system.

Development of micro scale forming machine had ben started 10 years ago. Groche et al. [3] made protoype of micro-forming machine with maximum capacity of $20 \mathrm{kN}$, and maximum speed of 1200 stroke/minutes. Main prime mover is linear motor with maximum slide speed: $110 \mathrm{~m} / \mathrm{s}^{2}$. Flexible $\mu$-Forming with capacity of $5.3 \mathrm{kN}$ was developed by Y. Qin et al. [4] with load-measurement resolution of sebesar $0.1 \mathrm{~N}$. Presz et al. [5] and Arentoft et al. [6] developed micro-forming machine with capacity of $5 \mathrm{kN}$ and $50 \mathrm{kN}$ using different actuator. Prescz used piezoelectric, while Arentoft used servo motor. Jie Xu et al. [7] develop micro-forming machine with capacity of $8.8 \mathrm{kN}$ and having positional resolution of $0.12 \mu \mathrm{m}$. Its maximum operating stroke speed was $1.1 \mathrm{~m} / \mathrm{s}$, while minimum speed was $5 \mu \mathrm{m} / \mathrm{s}$.

Micro-forming machine under investigation in this research was $5 \mathrm{kN} \mu$-Forming machine developed in Manufacturing Laboratory, Department of Mechanical Engineering, Universitas Indonesia. Some modification needs to be done to increase the performance of micro-forming machine. This modification changed the characteristic of machine. Therefore, characterization needs to be performed by geometric measurement and machine linier movement.

By the research, characterization of machine was expected to give technical reccomendation usefull for the user/operator of $5 \mathrm{kN} \mu$-Forming machine, beside technical specification from standard machine component.

\section{Methodology}

As mentioned before, mikro-forming machine under investigaion was $5 \mathrm{kN} \mu$ Forming machine developed by Manufacturing Laboratory, Department of Mechanical Engineering, Universitas Indonesia. The machine had been used for research on simple micro sheet metal forming process. Some modifications need to be done to increase performance of micro-forming machine. Some of them were change of type of prime mover, and changed of lower bolster component to increase capacity of machine chamber. Figure 1 was model CAD 3D and $2 \mathrm{D}$ of $5 \mathrm{kN} \mu$-Forming machine.

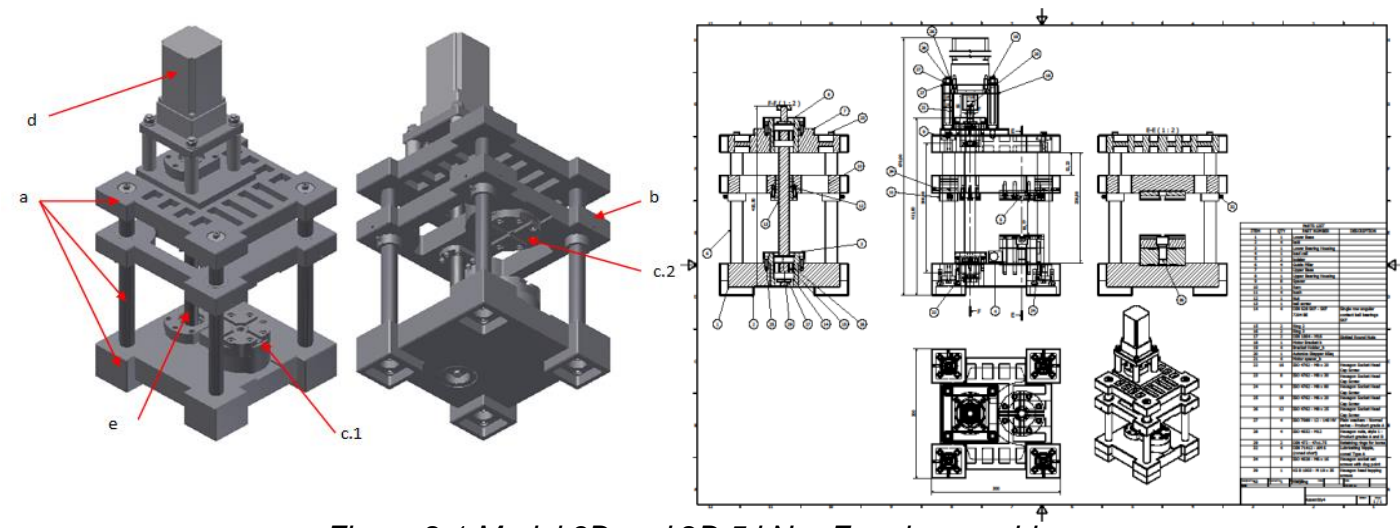

Figure 2.1 Model 3D and 2D $5 \mathrm{kN} \mu$-Forming machine

Part of micro forming machine: a). Frame \& guiding set; b). Ram; c). Bolster; d). Actuator; e). Ball screw

JEMMME | Journal of Energy, Mechanical, Material, and Manufacturing Engineering 
Before, $5 \mathrm{kN} \mu$-Forming machine was driven by Autonics type A140K - G599 - GB5 stepper motor. Then, to increase performance of machine, the motor was changed to servo motor type. The consideration on servo motor choice, were as follows:

1. Conformity of torque between designed maximum capacity and motor capacity.

2. Motor resolution.

3. Backlash.

4. Assembly of electric motor on machine.

Then, prime mover was changed to Oriental type NX940MS-PS10-3 servo motor, which equipped with SCX10 motor controller. Geometrical problems also became consideration, where motor dimension not to differ too much, so that motor foundation was not change. Table 1 below show the difference between two types of motor.

Table 2.1 Comparison of Electric Motor pecification

\begin{tabular}{|c|c|c|c|}
\hline Specificat & & A140K - G599 - GB5 & NX940MS-PS10-3 \\
\hline Max holding torque & {$[\mathrm{Nm}]$} & 14 & 34.3 \\
\hline $\begin{array}{l}\text { Moment of rotor } \\
\text { inertia }\end{array}$ & {$\left[\mathrm{kg} \cdot \mathrm{m}^{2}\right.$} & $27 \cdot 10^{-7}$ & $0,314 \cdot 10^{-4}$ \\
\hline Basic step angle & {$\left[{ }^{\circ}\right]$} & 0.144/0.072 (F/H step) & - \\
\hline Resolution & {$[\mathrm{P} / \mathrm{R}]$} & - & $\begin{array}{c}100-100000 \\
\text { (factory setting } 1000)\end{array}$ \\
\hline Gear ratio & & $1: 5$ & 10 \\
\hline $\begin{array}{l}\text { Allowable speed } \\
\text { range }\end{array}$ & [ rpm ] & 0 to 360 & 0 to 300 \\
\hline Backlash & {$\left[0^{\circ}\right]$} & 0.25 & 0.25 \\
\hline
\end{tabular}

Measurement of geometric tolerance was conducted based on Figure 2.2 below. The measurement was done by CMM Crysta Plus M44 machine.
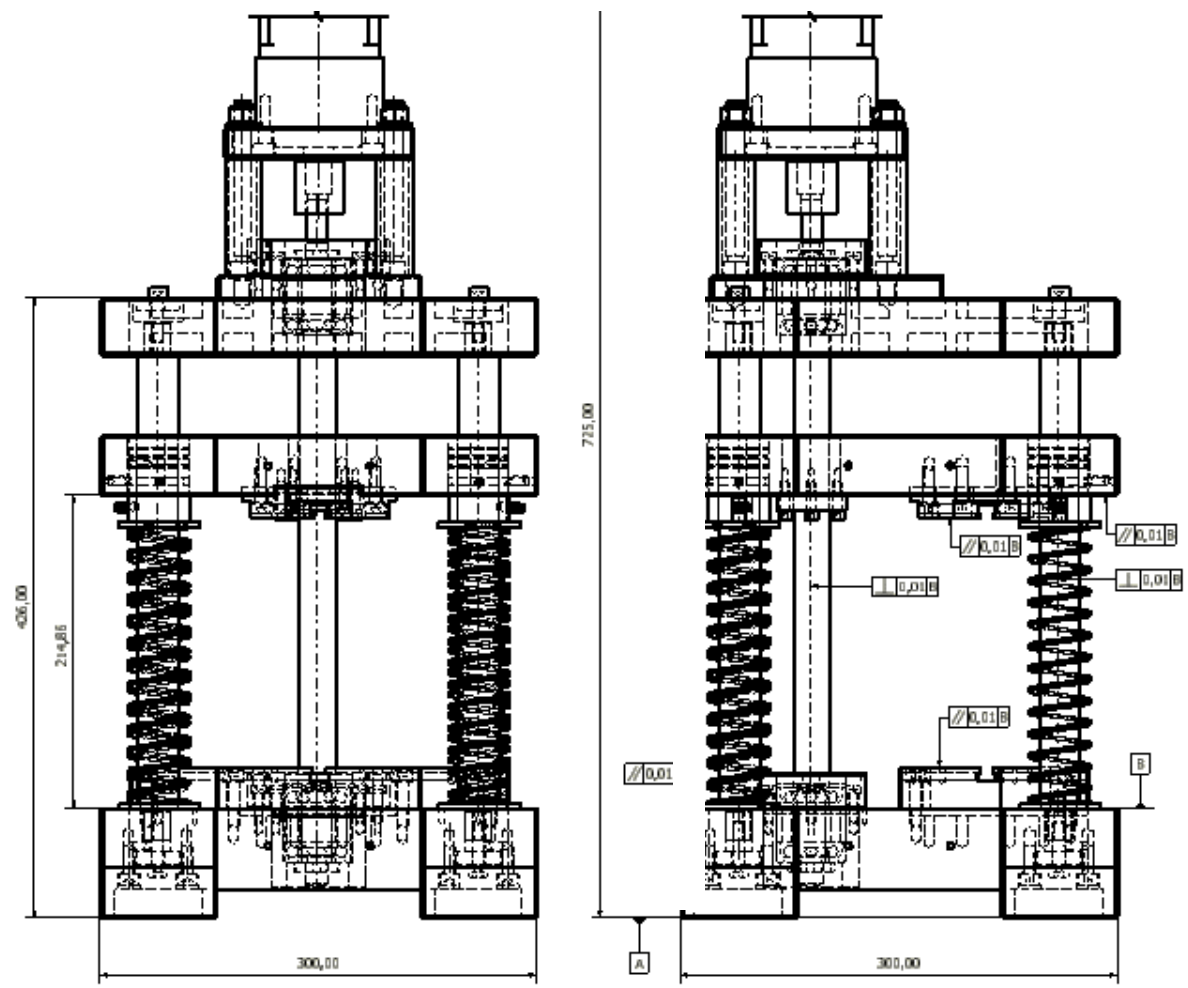

Figure 2.2 Geometric Tolerance of $5 \mathrm{kN} \mu$-Forming Machine 
Then, characterization of ram's linear movement was conducted to know difference between actual path distances with ideal/wanted distance. Ram component is the one with functions to convert rotational movement of motor shaft into linear movement and as carrier of componenet of upper micro-tool. To understand the character of ram movement, its needs the data on Table 2.2 below:

Table 2.2 Technical Data of Ball Screw and Servo Motor

\begin{tabular}{|c|c|c|c|}
\hline Ball srew & R25-5T3-FSI-500L & & \\
\hline & Nominal diameter & 25 & $\mathrm{~mm}$ \\
\hline & Lead & 5 & $\mathrm{~mm}$ \\
\hline & Backlash & 0,012 & $\mathrm{~mm} /$ rotation \\
\hline \multirow{7}{*}{$\begin{array}{l}\text { Motor } \\
\text { servo }\end{array}$} & NX940MS-PS10-3 & & \\
\hline & Max holding torque & 34.3 & $\mathrm{Nm}$ \\
\hline & $\begin{array}{l}\text { Moment of rotor } \\
\text { inertia }\end{array}$ & $0,314 \cdot 10^{-4}$ & $\mathrm{~J} / \mathrm{kg} \cdot \mathrm{m}^{2}$ \\
\hline & Resolution & $\begin{array}{c}100-100000 \\
\text { (factory setting 1000) }\end{array}$ & Pulse/rotation \\
\hline & Gear ratio & 10 & \\
\hline & $\begin{array}{l}\text { Motor permissible } \\
\text { speed }\end{array}$ & 3000 & $\mathrm{Rpm}$ \\
\hline & Backlash & 0,25 & \%/rotation \\
\hline
\end{tabular}

By using motor resolution of 100,000 , the resolution of linear movemen which can be achieved was $0.05 \mu \mathrm{m}$. Then, linear movement deviations which may be occurred caused by backlash on motor and ball screw on longest distance of path were as follows:

- Long distance of path $\quad=200 \mathrm{~mm}$

- Deviation of distance in 1 rotation of ballscrew $=0,012 \mathrm{~mm}$

- Deviation of distance in 1 rotation of motor shaft $=0,00347 \mathrm{~mm}$

- Total deviatioin along longest path $\quad=0,6188 \mathrm{~mm}$

Deviation of linear movement was not only caused by backlash on ballscrew and gear in motor. The clearance between other components related to transmition of rotary movement to linear movement need to be concerned.

As initial point of measurement, it was decided to start on position of upper bolster and lower bolster with distance of $120 \mathrm{~mm}$. Length of measuring path was decided between $10 \mathrm{~mm}$ to $70 \mathrm{~mm}$ from starting point, in interval of $10 \mathrm{~mm}$. This arrangement was based on gemetric data on the height of employed micro tool, in which:
a. Micro blanking
: $65.5 \mathrm{~mm}$
b. Micro L-Bending : $115.6 \mathrm{~mm}$
c. Micro V-Bending : $119 \mathrm{~mm}$

Figure 3 below explain the starting point of measurement (A). Upper bolster and lower bolster components were positioned in touch each other. Then, ram component which was the supporting platform for upper bolster was translated along $120 \mathrm{~mm}$ with motion parameter as follows:
Distance
$=12000 \mathrm{p} 10 \mathrm{um}$
Starting velocity $\quad=0.1 \mathrm{p} 10 \mathrm{um} / \mathrm{sec}$
Running velocity $=50 \mathrm{p} 10 \mathrm{um} / \mathrm{sec}$
Acceleration
$=0.5 \mathrm{sec}$
Deceleration
$=0.5 \mathrm{sec}$

From the measurement results, the actual distance was $119.761 \mathrm{~mm}$, and the difference with actual travel distance was $0.239 \mathrm{~mm}$. Ram component then moved down for distance of $10 \mathrm{~mm}$ and its multiplication. Then the component moved up to its initial position. Whole movement is in 1 cycle of movement. 

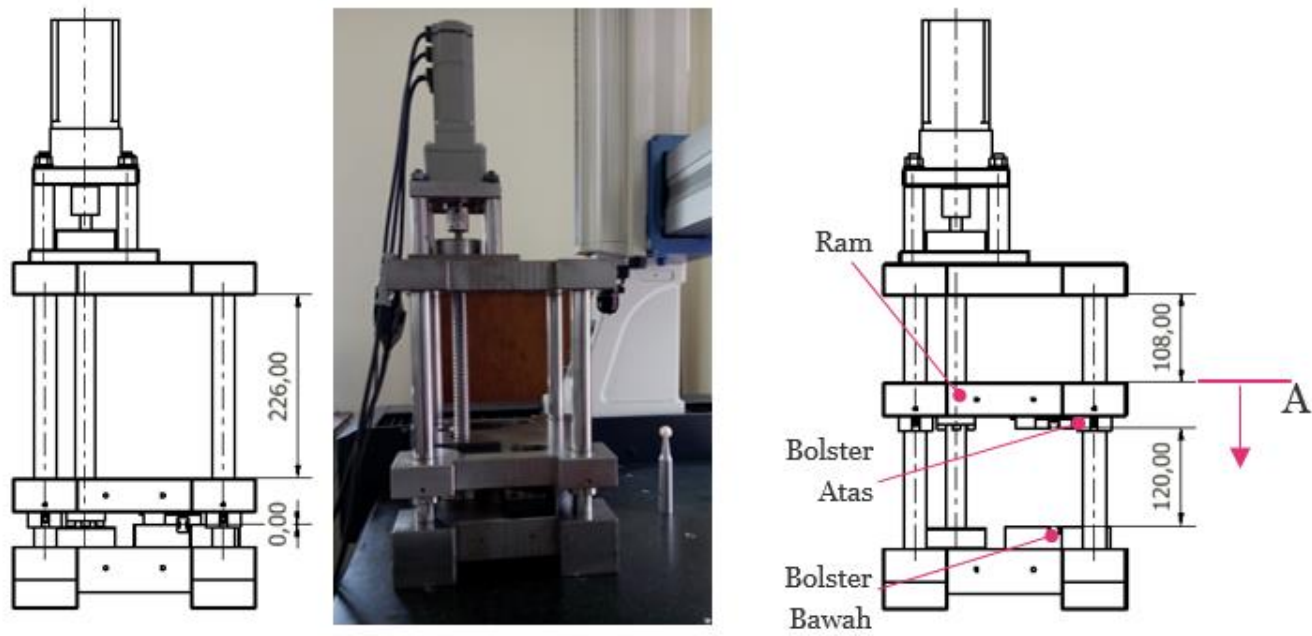

Figure 2.3 Setting of Zero Position of Measurement

\section{RESULT AND Discussion}

From the measurement of geometric deviation on $5 \mathrm{kN} \mu$-Forming Machine, the results was presented in Table 3.1 as follows. The data showed the good results. The lining of upper surface of lower base with lower surface of foundation was caused by machine foundation was not grind when it assembled with lower base. But it was not a main problem because other components was assembled on lower base, and geometric deviation showed good results.

Table 3.1 Measurement Result of Geometric Tolerance of $5 \mathrm{kN} \mu$-Forming

\begin{tabular}{llllll}
\hline No. & \multicolumn{1}{c}{$\begin{array}{c}\text { Geometric } \\
\text { Tolerance }\end{array}$} & \multicolumn{1}{c}{ Datum } & $\begin{array}{c}\text { Nominal } \\
\text { of } \\
\text { tolerance } \\
{[\mathrm{mm}]}\end{array}$ & $\begin{array}{c}\text { Measurement } \\
\text { result [mm] }\end{array}$ & $\begin{array}{c}\text { Out Tol } \\
{[\mathrm{mm}]}\end{array}$ \\
\hline 1 & $\begin{array}{l}\text { Lining of upper } \\
\text { surface of lower } \\
\text { base (B) }\end{array}$ & $\begin{array}{l}\text { Lower surface of } \\
\text { foundation (A) }\end{array}$ & 0,01 & 0,0312 & 0.0212 \\
\hline 2 & $\begin{array}{l}\text { Lining of lower } \\
\text { surface of ram }\end{array}$ & $\begin{array}{l}\text { Upper surface of } \\
\text { lower base (B) }\end{array}$ & 0,01 & 0,0079 & 0,0000 \\
\hline 3 & $\begin{array}{l}\text { Orthogonality of } \\
\text { guiding rod }\end{array}$ & $\begin{array}{l}\text { Upper surface of } \\
\text { lower base (B) }\end{array}$ & 0,01 & 0,0000 & 0,0000 \\
\hline 4 & $\begin{array}{l}\text { Orthogonality of } \\
\text { ball screw }\end{array}$ & $\begin{array}{l}\text { Upper surface of } \\
\text { lower base (B) }\end{array}$ & 0,01 & 0,0000 & 0,0000 \\
\hline 5 & $\begin{array}{l}\text { Lining of upper } \\
\text { surface of lower } \\
\text { bolster }\end{array}$ & $\begin{array}{l}\text { Upper surface of } \\
\text { lower base (B) }\end{array}$ & 0,01 & 0,0001 & 0,0000 \\
\hline 6 & $\begin{array}{l}\text { Lining of lower } \\
\text { surface of upper } \\
\text { bolster }\end{array}$ & $\begin{array}{l}\text { Upper surface of } \\
\text { lower base (B) }\end{array}$ & 0,01 & 0,0070 & 0,0000 \\
\hline
\end{tabular}

JEMMME | Journal of Energy, Mechanical, Material, and Manufacturing Engineering 
Table 3.2 Difference of path distance with measured distance on go-down movement ( $\square / 1-2)$

\begin{tabular}{cccccccc}
$\mathbf{n}$ & \multicolumn{7}{c}{ Path distance [mm] } \\
\cline { 3 - 8 } & $\mathbf{1 0}$ & $\mathbf{2 0}$ & $\mathbf{3 0}$ & $\mathbf{4 0}$ & $\mathbf{5 0}$ & $\mathbf{6 0}$ & $\mathbf{7 0}$ \\
\hline $\mathbf{1}$ & 0.1160 & 0.1295 & 0.0660 & 0.0820 & 0.0665 & 0.0900 & 0.1190 \\
\hline $\mathbf{2}$ & 0.1215 & 0.1299 & 0.0850 & 0.0625 & 0.0735 & 0.0680 & 0.0905 \\
\hline $\mathbf{3}$ & 0.1260 & 0.1145 & 0.0595 & 0.0695 & 0.0775 & 0.0730 & 0.1495 \\
\hline
\end{tabular}

The test result of linear movement of machine was summarized in Table 3.2 to Table 3.4, and was presented in Figure 3.1 to Figure 3.3. The unit measurement table and figure were millimeter. Difference between path distances with measured distance in go down movement $\left(\square_{11-2}\right)$ was shon in Table 3.2 and Figure 3.1. The difference was in range of $0.0595 \mathrm{~mm}$ to $0.1495 \mathrm{~mm}$. The consistent tendency was prominent in 3rd data set to 6 -th data set.
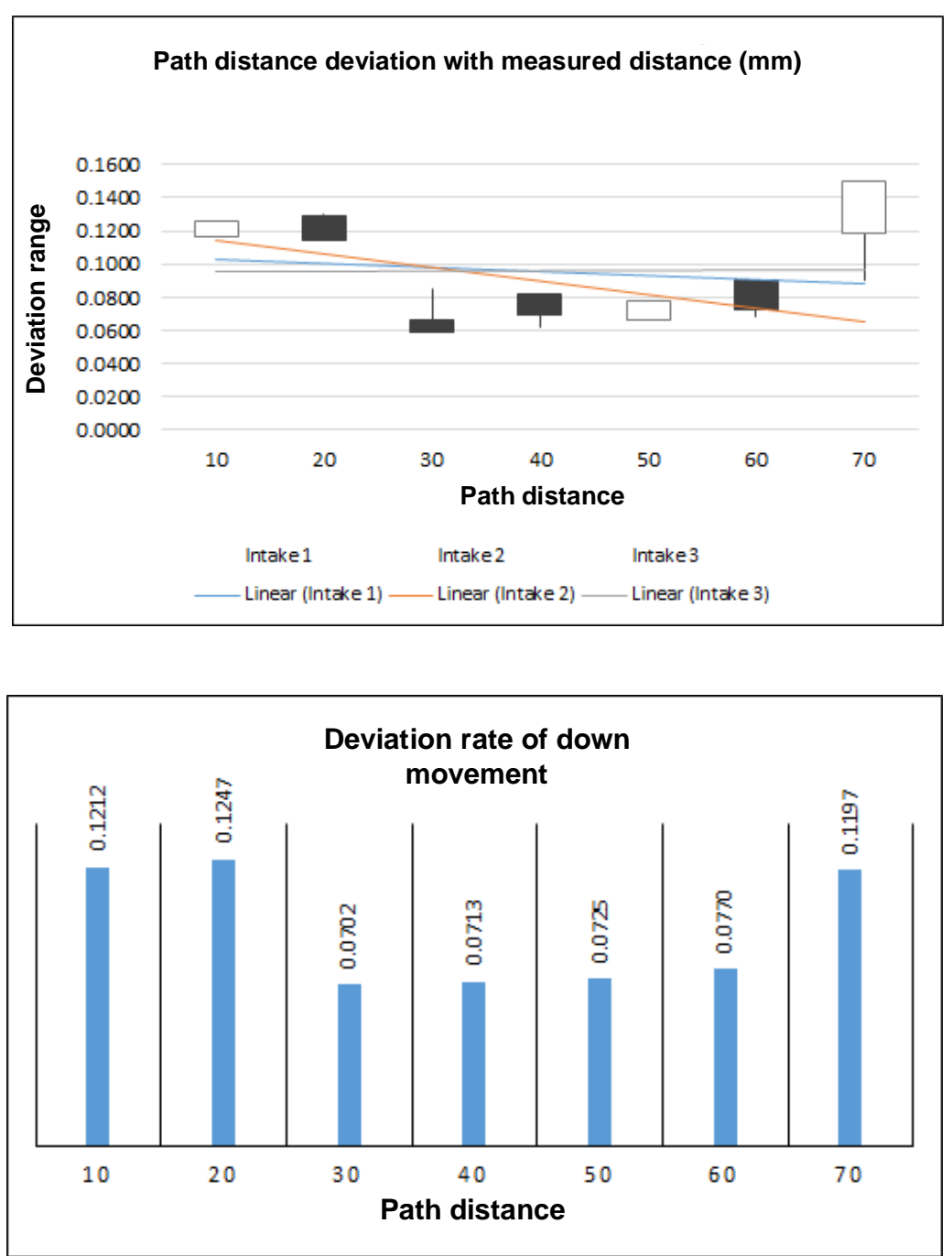

Figure 3.1 Graph of Difference of Path Distance with Measured Distance for go-down movement ( $\square$ 11-2)

The difference of path distance with measured distance for go-up movement was presented in Table 3.3 and Figure 3.2. The difference was in range of $0.0640 \mathrm{~mm}$ to $0.1390 \mathrm{~mm}$. Similar to profile of go-down movement, the consistent tendency was shown from 3 rd data set to 6 th data set. 
Table 3.3 Difference of Path Distance with Measured Distance for go-up movement $(\square$ I2-3)

\begin{tabular}{|c|c|c|c|c|c|c|c|}
\hline \multirow{2}{*}{$n$} & \multicolumn{6}{|c|}{ Path Distance } & \multirow[b]{2}{*}{70} \\
\hline & 10 & 20 & 30 & 40 & 50 & 60 & \\
\hline 1 & 0.1185 & 0.1430 & 0.0640 & 0.0740 & 0.0735 & 0.0795 & 0.1180 \\
\hline 2 & 0.1220 & 0.1270 & 0.0745 & 0.0660 & 0.0705 & 0.0715 & 0.0910 \\
\hline 3 & 0.1270 & 0.1150 & 0.0705 & 0.0655 & 0.0810 & 0.0780 & 0.1390 \\
\hline
\end{tabular}

Table 3.4 and Figure 3.2 showed summary of data measurement for observing precision of ram for 1 cycle and back to initial position (position A, Figure 2.3).

From Table 3.4 and Figure 3.2, it was shown that deviation of ram movement precision was in range of $-0.0135 \mathrm{~mm}$ to $0.0105 \mathrm{~mm}$. The tendency of movement profile was not onsistent enough, where on 2nd data set (path distance of $20 \mathrm{~mm}$ ) showed highest range of deviation compared with other. The next data set showed decrease in deviation range, but go increase again on 7th data set.
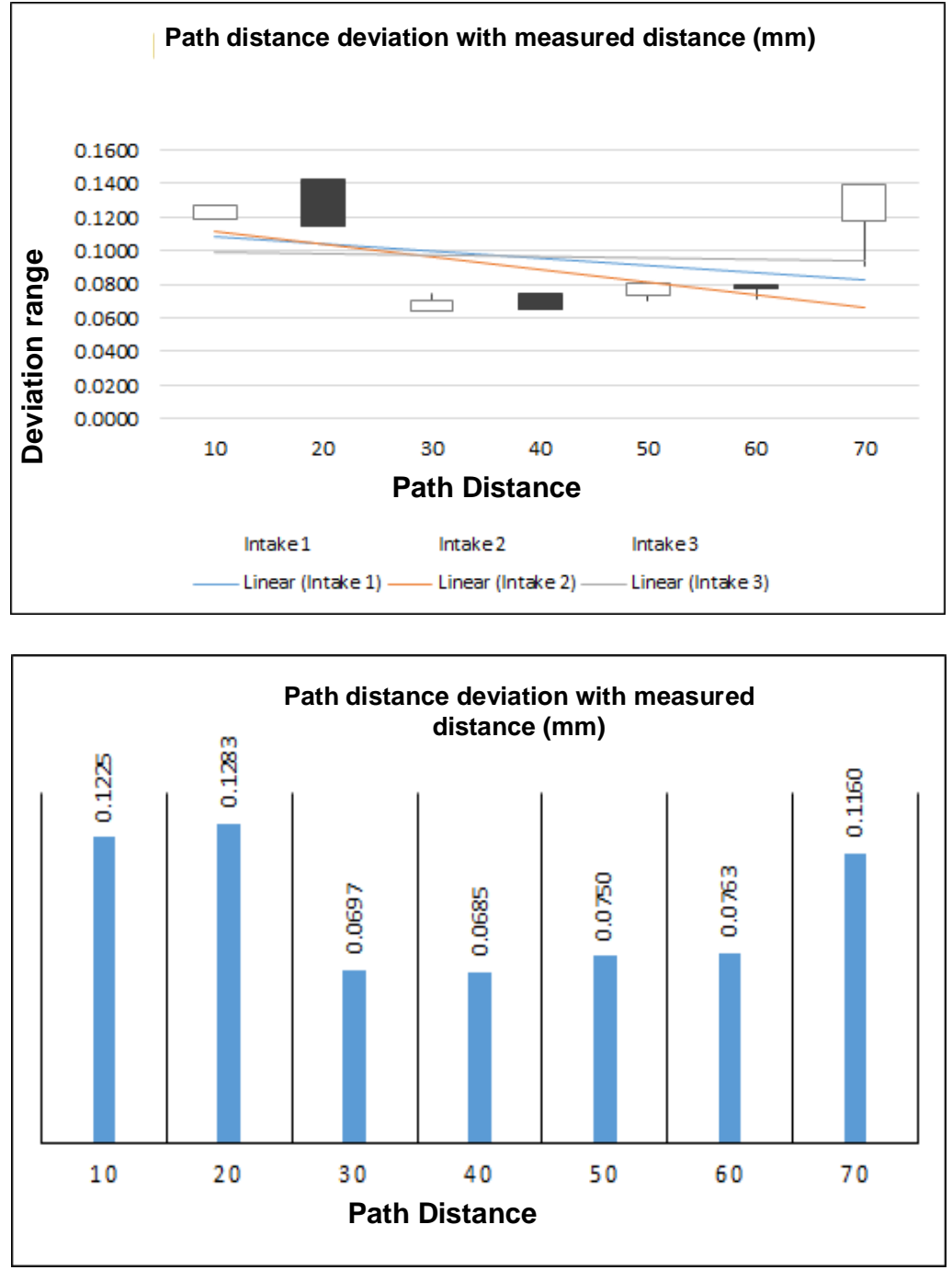

Figure 3.2 Graph of Difference of Path Distance with Measured Distance for go-up movement ( $\square 12-3)$ 
Table 3.4 Difference of go-up and go-down ram movement for 1 cycle $(\Delta, 1-3)$

\begin{tabular}{ccrrrrrr}
\hline $\boldsymbol{n}$ & $\mathbf{7}$ Path Distance [mm] \\
\cline { 2 - 8 } & $\mathbf{1 0}$ & $\mathbf{2 0}$ & $\mathbf{3 0}$ & $\mathbf{4 0}$ & $\mathbf{5 0}$ & $\mathbf{6 0}$ & $\mathbf{7 0}$ \\
\hline $\mathbf{1}$ & -0.0025 & -0.0135 & 0.0020 & 0.0080 & -0.0070 & 0.0105 & 0.0010 \\
\hline $\mathbf{2}$ & -0.0005 & 0.0030 & 0.0105 & -0.0035 & 0.0030 & -0.0035 & -0.0005 \\
\hline $\mathbf{3}$ & -0.0010 & -0.0005 & -0.0110 & 0.0040 & -0.0035 & -0.0050 & 0.0105 \\
\hline
\end{tabular}
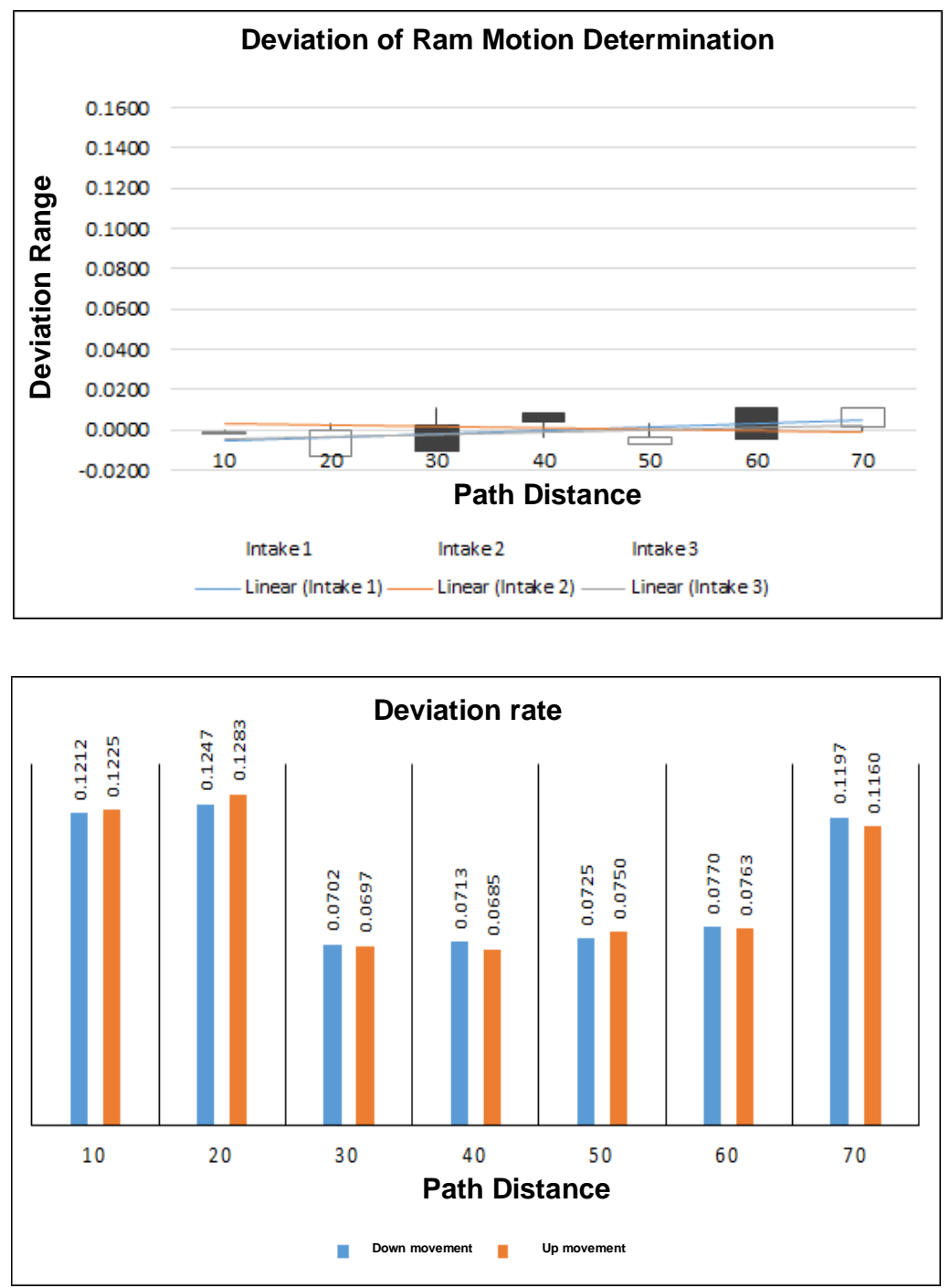

Figure 3.3 Graph of Deviation of ram movement precison for 1 cycle movement

When look at in general, profile of ram movement precision showed good average. Average deviation for go-up and go-down data showed small difference in value. It means the movement of ram component on negative direction (go-down) showed same path distance as on positive direction (go-up) in one cycle. Therefore, it can be concluded that performance of prime mover, i.e. electric motor, and machine construction was reliable enough to be used for micro-forming process. 


\section{Conclusion}

Characterization of $5 \mathrm{kN} \mu$-Forming machine by measurement of geometry and linear movement test had been conducted with the results as follows:

1. Deviation caused by geometric imperfection of assembled machine component showed good result. Almost all target of measurement showed value below permitted deviation.

2. Movement of ram component for positive direction (go-up) or negative direction (godown) showed similar pattern. In path distance of $30 \mathrm{~mm}, 40 \mathrm{~mm}, 50 \mathrm{~mm}$, and 60 $\mathrm{mm}$, the average differnce of expected path distance with actual measuremt showed value under $0.1 \mathrm{~mm}$. Meanwhile in path distance of $10 \mathrm{~mm}, 20 \mathrm{~mm}$, and $70 \mathrm{~mm}$, the average of expected path distance with actual measurement showed value above $0.1 \mathrm{~mm}$.

3. Testing of linear movement of machine for 1 cycle movement showed range of deviation of $0.024 \mathrm{~mm}$ with smallest deviation of $-0.0135 \mathrm{~mm}$ and biggest deviation of $0.0105 \mathrm{~mm}$. Deviation value was still below estimated of backlash from mathematical analysis.

4. Result of testing on linear movement of machine gave reccomendation on effective work path of $5 \mathrm{jN} \mu$-Forming machine, i.e. on path distance of $30 \mathrm{~mm}$ to $60 \mathrm{~mm}$, from A point which decided before.

5. Performance of prime mover and machine construction was reliable to be used for micro-forming process because deviation average of go-up and go-down movement showed small difference. Its mean that movement of ram on negative direction (godown) showed path distance similar to movement in positive direction (go-up) in one cycle.

\section{REFERENCES}

[1] Koc, M., Özel, T. 2011. Micro-Manufacturing: Design and Manufacturing of MicroProducts. 1st ed. Canada: John Wiley \& Sons, Inc.

[2] Mahmudah, A. 2013.Pengembangan Mesin Micro Forming untuk Proses manufaktur Part Mikro. Master. Teknik Mesin. Universitas Indonesia. Depok.

[3] Groche, P., Schneider, R. Method for the Optimization of Forming Presses for the Manufacturing of Micro Parts. CIRP Annals - Manufacturing Technology. 2004; 53: $281-284$.

[4] Qin, Y., Ma, Y., Harrison, C., Brockett, A., Zhou, M., Zhao, M., et al. Development of a new machine system for the forming of micro-sheet-products. International Journal of Material Forming. 2008; 1: 475 - 478.

[5] Presz, W., Andersen, B., Wanheim, T. Piezoelectric driven Micro-press for microforming. Journal of Achievements in Materials and Manufacturing Engineering. 2006; 18.

[6] Arentoft, M., Eriksen, S, R., Hansen, N, H., Paldan, A, N. Towards the first generation micro bulk forming system. CIRP Annals-Manufacturing Technology. 2011; 60: 335 338.

[7] Xu, J., Guo, B., Shan, D., Wang, C., Li, J., Liu, Y., et al. Development of a microforming system for micro-punching process of micro-hole arrays in brass foil. Journal of Materials Processing Technology. 2011/2012; 212: 2238 - 2246. 